\title{
High-Performance Work Systems and Proactive Behavior: The Mediating Role of Psychological Empowerment
}

\author{
Md. Shamsul Arefin ${ }^{1}$, Ishtiaque Arif $^{2} \&$ Muhammad Raquib $^{2}$ \\ ${ }^{1}$ School of Management, Huazhong University of Science and Technology, Wuhan, P. R. China \\ ${ }^{2}$ School of Business Studies, Southeast University, Dhaka, Bangladesh \\ Correspondence: Md. Shamsul Arefin, Room-303, School of Management, Huazhong University of Science and \\ Technology, Wuhan, 430074, Hubei, P. R. China. E-mail: arefin@hust.edu.cn
}

Received: January 4, 2014

Accepted: February 2, 2015

Online Published: February 27, 2015

doi:10.5539/ijbm.v10n3p132

URL: http://dx.doi.org/10.5539/ijbm.v10n3p132

\begin{abstract}
Drawing on social exchange theory, this study explores the relationship between high-performance work systems (HPWS) and proactive work behavior. We also examined whether psychological empowerment mediated the effects of HPWS on employees' proactive behavior. Using a sample of 247 employees employed by three large manufacturing firms in Bangladesh, results from structural equation modeling and hierarchical regression analyses showed that HPWS was positively related to proactive behavior. The results also suggested that psychological empowerment mediated the relationship between HPWS and proactive behavior. The theoretical and practical implications of these findings are discussed.
\end{abstract}

Keywords: proactive behavior, psychological empowerment, high-performance work systems

\section{Introduction}

Because of increasing pressure to shift the work toward decentralization, flexibility, continuous innovation, and changes, the organizations are demanding proactive employees who are willing to take initiatives in solving organizational problems and improving current circumstances (e.g., Crant, 2000; Parker, Williams, \& Turner, 2006). However, organizational human resources (HR) strategies help organization to gain a competitive advantage and become successful, which are quite unachievable without the employees' drive to solve organizational problems and change its structure spontaneously (Parker et al., 2006). Proactive work behaviors refer to the anticipatory actions and initiatives that are undertaken by employee to bring changes or develop existing situations (Crant, 2000; Den Hartog \& Belschak, 2012). Proactive behavior stems from person-related variables (Parker \& Collins, 2010) and contextual factors (Morrison \& Phelps, 1999). For its vast impact on organization, proactive behavior has become an important concept (Crant, 2000). Surprisingly, despite the research call (Grant \& Ashford, 2008) and consensus that proactive behavior can be boosted via contextual influences, no prior research has been devoted to explore how strategic human resource management (SHRM) systems foster proactive behavior.

As contextual cues, high-performance work systems (HPWS) might have some impacts on employee proactive behavior. HPWS are composed of couples of HR practices that perform as systems and act upon each other. The common practices in HPWS include staffing, training, developmental performance appraisal, motivational remuneration, and flexible job assignments (Takeuchi, Lepak, Wang, \& Takeuchi, 2007). Prior research suggests that HPWS have a profound impact on employee behaviors (Becker, Huselid, Pickus, \& Spratt, 1997). However, research reveals that the intended HPWS are different from employee perceived HPWS (Bowen \& Ostroff, 2004). Keeping this as evidence, the current study intended to consider employee perceived HPWS. Although prior research emphasized the effect of HPWS on job performance and extra-role behavior, as behavioral outcomes, research suggests that employees may demonstrate proactive behaviors while they are performing the assigned tasks and displaying discretionary behaviors (Crant, 2000).

While the influence of HPWS on numerous work-related outcomes is well understood, it does not explicitly reveal the underlying mechanism through which the systems of HR impact work-related outcomes, especially proactive behaviors. This study, therefore, intends to explore the impact of employee perceived psychological empowerment in HPWS-proactive behavior relationship. Psychological empowerment, which represents the individual's feeling 
of some control over their surroundings and experience meaning in what they do, may act as a possible mediating mechanism. Psychological empowerment is a motivational factor that explains the individual's perception of empowerment (Spreitzer, 1995; Menon, 2001) and instills employees to work-related behaviors.

The present study contributes to the extant SHRM literature, incorporating employee proactive behavior as an outcome of HR systems. In contrast, aiming to extend proactive behavior literature, this study exemplifies that the HPWS as contextual cues affect employee proactive behavior. Furthermore, the current study tends to explore the mediating role of psychological empowerment in the relationship between HPWS and employee proactive behaviors.

\section{Theoretical Background and Hypotheses}

\subsection{HPWS and Proactive Behavior}

HPWS are constituted such HR practices that may motivate employees to exert the desired behavior that is consistent to the organizational strategy. HPWS impact employees' ability, motivation and potentials to develop (Wright \& Boswell, 2002). Moreover, HPWS play a synergistic role with the organizational strategies that lead to higher performance (Becker \& Gerhart, 1996; Schuler \& Jackson, 1987). Although researchers debate differently on which HR practices constitute HR systems, a shared agreement has been argued for those practices which increase the employees' capabilities, motivation, and potentials to develop (Wright \& Boswell, 2002). In line with this understanding, the present study entails HR practices comprised in HPWS, such as recruitment, training, performance-based remuneration, developmental appraisal systems, flexible job environment, and participative management.

Proactive behavior is a type of motivated and change-focused work behavior (Bateman \& Crant, 1993). Although the concept of proactive behaviors is defined differently, a common consensus emerges among the researchers on the behaviors such as change-focused and problem solving initiatives (Crant, 2000; Grant \& Ashford, 2008). Peoples with proactivity are more likely to seek information and bring ideas spontaneously toward substantial changes in their surroundings (Crant, 2000). Furthermore, by their own initiatives, proactive employees come forward in solving the organizational problems and make attempts to block the reoccurrence of problems applying self-defined methods (Parker et al., 2006). Grant \& Ashford (2008) described the difference between proactive behaviors and motivated behavior and reactive behavior in two aspects, such as acting in advance and intended impact. Being proactive, employee acts in advance with more anticipative, agentic and mindfulness. On the other side, keeping firm intention to change the environment, employee aims to bring more visible results. Proactive behaviors are sought by employees to change themselves, their peers, or the environment (Grant \& Ashford, 2008). Moreover, proactive behavior entails behaviors such as anticipating, planning, solving problems and searching ways to change the current circumstances (Parker \& Collins, 2010; Parker et al., 2006). A body of researchers has revealed the influence of HPWS on employee work-related behaviors such as in-role and extra-role behaviors including citizenship and creativity behaviors (e.g., Chang, Jia, Takeuchi, \& Cai, 2014; Kehoe \& Wright, 2013).

As the adoption of HPWS motivates employees, it is argued that employees feel responsible to take initiatives in solving problems and changing the current circumstances beyond their work-related task. To describe the relationships between HPWS and proactive behavior, we employ social exchange perspective (Blau, 1964), which explains the dynamics of resource exchanges between two or more parties. Furthermore, when employees get benefit from their organization, they are more likely to take initiative to sustain mutually beneficial and long-term relationships with their organization. When employees see any favor to them from an organization that incorporates favorable policies and practices, they are more likely to give the feedback by performing their job, even doing more than the desired performance. In general, organization shapes employees' perception through incorporating HPWS.

HPWS send signals from an organization to its employees that employees' capabilities are valued by an organization and in turn, they come forward to solve organizational problems deliberately. Undertaking a pool of motivating HR practices, such as selective recruitment, extensive training, developmental performance appraisal, motivating compensation, participative management, and flexible work design, organizations send messages to employees that their capabilities and efforts are recognized and valued. When employees perceive signals from their work environment that they are valued and important, they are more likely to take initiative to solve organizational problems and bring change to organizational betterment. Job autonomy as a form of participative management motivates employees to show proactive behavior (Parker et al., 2006). Recently, Den Hartog and Belschak (2012) have suggested that the enhanced investment in training and coaching may increase employees' proactive work behavior. Therefore, we can predict the first hypothesis:

Hypothesis 1: There is a positive relationship between HPWS and proactive behaviors. 


\subsection{HPWS and Psychological Empowerment}

Empowerment is viewed as more commitment-oriented, that is the opposite of control-oriented perspective (Walton, 1985). Psychological empowerment encourages employees to think about their capabilities to accomplishing the jobs, develop the meaning of the task, and have the confidence to influence the organization through their work roles. A four-dimensional psychological empowerment is suggested by Spreitzer (1995). The first dimension is meaning, which is defined as the feeling of importance of one's own work roles. Secondly, competence signifies the feelings of confidence in performing the assigned tasks by virtue of one's own capabilities. Impact describes the perception of influence over the individual's working environment. Autonomy refers to the freedom of choosing an individual's own way to accomplish the task. To constitute a composite factor, it is important to integrate these four dimensions; any lack of single dimension decreases the overall extent of perceived empowerment. The influence of work context on the psychological empowerment is recognized in the empowerment literature (Grant \& Ashford, 2008). In HPWS adopted organization, employees are encouraged to consult with their supervisors regarding organizational problems and their jobs. Participative management is imbedded with increased job autonomy and empowerment (Seibert, Wang, \& Courtright, 2011). As HPWS are associated with a high job autonomy, employees feel to have more autonomy and freedom once HPWS is undertaken (Appelbaum, Bailey, Berg, \& Kalleberg, 2000; Castanheira \& Chambel, 2010; Carvalho \& Chambel, 2014). The compensation systems subject to employee performance will motivate employees to feel self-determination at work. Extensive training programs improve employees' capabilities, which further motivate them to be confident on making an impact on the organization. Moreover, participative management enables employees to feel more control over the assigned tasks. Thus, we can hypothesize:

\section{Hypothesis 2: There is a positive relationship between HPWS and psychological empowerment.}

\subsection{Psychological Empowerment and Proactive Behavior}

Empowered employees feel more comfortable and less constrained by their jobs, such that they are more likely to help others and be proactive in their jobs. Moreover, empowered employees feel more identified with their jobs that further motivate them to help organization. Spreitzer (1995) has identified the influence of psychological empowerment on employees' desired behaviors. Meaning instills employees to be committed and action focused. When employees feel their jobs as meaningful, they are more likely to collect information from various sources enthusiastically and spend more effort to solve the problems deliberately (Gilson \& Shally, 2004). Competence gives confidence to overcome all problems that are contingent to situations. Self-determination and impact also encourages diligence. When employees are more encouraged with high empowerment and autonomy, they tend to display proactive behavior. For example, the feeling of empowerment motivates employees to share novel ideas and engage in change-oriented behaviors (Amabile, Conti, Coon, Lazenby, \& Herron, 1996). Thus, the following hypothesis is predicted:

\section{Hypothesis 3: There is a positive relationship between psychological empowerment and proactive behavior.}

\subsection{Psychological Empowerment as a Mediator}

Psychological empowerment can mediate the influences of contextual factor such as HPWS, on employees' work-related behaviors such as proactive behavior. As employees' attitudes and behavior are contingent to organizational practices, we argue for the intervening role of psychological empowerment through which employee perceived HPWS influence proactive behavior. Although the intervening role of psychological empowerment in HPWS-in-role behavior linkage is examined in prior research (e.g., Aryee, Walumbwa, Seidu, \& Otaye, 2012; Butts, Vandenberg, DeJoy, Schaffer, \& Wilson, 2009; Liao, Toya, Lepak, \& Hong, 2009), a more detailed explanation is solicited which explore the reason for HPWS-proactive behavior linkage. We propose that psychological empowerment may explain why employees display proactive behavior in response to HPWS. HPWS as situational factors shape employees' understanding of enhanced freedom over their works, which motivate them to feel a high level of psychological empowerment (Liao et al, 2009), in turn, employees are more likely to show change-oriented and problem solving initiatives.

Hypothesis 4: Psychological empowerment mediates the positive relationship between HPWS and proactive behavior.

\section{Research method}

\subsection{Sample and Study Design}

To examine our hypotheses, we collected data from three large private pharmaceutical firms in Bangladesh. For greater understanding, we translated the items, which were originally in English form, into Bengali. Following Brislin (1980), we back translated into English. We targeted the full-time employees and their immediate 
supervisors in various departments of each company. Two sets of questionnaires with cover letters were prepared to get the responses. HPWS and psychological empowerment items were rated by employees. The employee's supervisor was asked to rate subordinate's proactive behavior. The questionnaires were distributed with the help of human resource managers during the work time. A cover letter explaining the survey objectives, guidelines for response was delivered to get the highest response. Each employee's ID was taken and mentioned on the envelope of each set of questionnaire so that matching with his or her supervisor was tracked. All respondents were assured to keep confidentiality of their responses. A total of 247 responses were received with a response rate of 76 percent. Among employees, 68\% (168) were male. In terms of education, a total of $118(47.8 \%)$ employees had received Higher Secondary School certificate. Most of the employees' age 80.2\% (198) were below 40 years and organizational tenure $81.3 \%$ (176) were below 10 years.

\subsection{Measures}

Existing measures from past research were used. All of the constructs were measured using multiple items and a five-point scale ending with $1=$ strongly disagree and $5=$ strongly agree.

\subsubsection{HPWS}

We measured employee perceived HPWS by using 18 items frequently used in prior research (e.g., Chuang \& Liao, 2010; Lepak \& Snell, 2002; Sun, Aryee, \& Law, 2007). These items involve six typical practices of HPWS-staffing (e.g., Selection process is comprehensive"), training (e.g., The company continuously provides training programs), developmental performance management (e.g., Performance appraisals are based on objective, quantifiable results), motivational compensation (e.g., The company attaches importance to the fairness of compensation/rewards", flexible work design (e.g., The company has its ways or methods to help employees alleviate work stress), and participative decision making (e.g., If a decision made might affect employees, the company asks them for opinions in advance). The mean scores of all practices were measured to represent this variable and the Cronbach's alpha was .91.

\subsubsection{Psychological Empowerment}

We employ a twelve-item scale developed by Spreitzer (1995). Sample items: "The work I do is very important to me," "I am confident about my ability to do my job," "I have significant autonomy in determining how I do my job," and "My impact on what happens in my organization is large." Following prior research (Aryee et al., 2012; Liden, Wayne, \& Sparrowe, 2000) we used a composite measure of psychological empowerment. The reliability alpha was 96.

\subsubsection{Proactive Behaviors}

This study used Parker et al. (2006) eight-item scale to evaluate employee proactive behaviors rated by supervisor. The sample items read: "The employee implements ideas for improvements by him/herself," "The employee suggests ideas for improvements to manager, supervisor, or others," "The employee tries to sort out the problem so it will not happen again," and "The employee tries to figure out why reject levels are increasing." The alpha value was .87 .

\subsubsection{Control Variables}

Employees' age, education, gender, and organizational tenure were taken as control variables. Age was measured on a scale from 1 ( 18 years to 29 years) to 6 (70 years and above) with 10-year intervals. Gender was measured with two variables (i.e., $1=$ male, $0=$ female). Education level included five categories ranging from " $1=$ middle school or below" to " $5=$ master's degree or above". Organizational tenure was measured in years.

Table 1. Confirmatory factor analysis

\begin{tabular}{lcccccc}
\hline \multicolumn{1}{c}{ Model } & $\chi^{2}$ & $d f$ & $\chi^{2} / d f$ & CFI & TLI & RMSEA \\
\hline Null model & 3930.57 & 231 & & & & \\
Three-factor model & 472.26 & 206 & 2.29 & 0.93 & 0.92 & 0.07 \\
Two-factor model A & 626.70 & 208 & 3.01 & 0.89 & 0.87 & 0.09 \\
Two-factor model B & 784.23 & 208 & 3.77 & 0.84 & 0.83 & 0.11 \\
Two-factor model C & 873.60 & 208 & 4.2 & 0.82 & 0.80 & 0.11 \\
One-factor model & 1129.22 & 209 & 5.40 & 0.75 & 0.63 & 0.13 \\
\hline
\end{tabular}

Notes. CFI = comparative fit index; TLI = Tucker-Lewis index; RMSEA = root mean square error of approximation. Two-factor model A: HPWS and proactive behavior were combined into one factor; Two-factor model B: psychological empowerment and HPWS were combined into one factor; Two-factor model C: psychological empowerment and proactive behavior were combined into one factor; One-factor model: HPWS, psychological empowerment and proactive behavior were combined into one factor. 


\section{Results}

\subsection{Measurement Issues}

To identify the discriminant validity, we run the confirmatory factor analyses in Amos 17. The confirmatory factor analysis is generally used to distinct the study constructs by comparing the chi-square of the hypothesized model with the alternative model. If the chi-square is significantly smaller in the hypothesized model, discriminant validity has been shown (Segars, 1997). A total of four alternative models were compared with the hypothesized three-factor model. Table 1 shows the result of confirmatory factor analysis describing a significantly well data fit for hypothesized three-factor model $\left(\chi^{2}=472.26, d f=206, \chi^{2} / d f=2.29, p<.01\right.$, CFI $=0.93$, TLI $=0.95$, RMSEA $=0.07$ ) and confirms the recommendation of Kline (1998) for cutoff value of .08 or less for RMSEA, less than 3 for $\chi^{2} / d f$ ratio, greater than .90 for CFI and TLI for good model fit. Therefore, it seems the results satisfy the conditions for discriminant validity. Means, standard deviations, and correlations of all variables were depicted in Table 2.

Table 2. Means, standard deviations, and correlations

\begin{tabular}{|c|c|c|c|c|c|c|c|c|c|}
\hline Variables & $M$ & $S D$ & 1 & 2 & 3 & 4 & 5 & 6 & 7 \\
\hline 1. Age & 1.98 & 0.73 & & & & & & & \\
\hline 2. Gender ${ }^{a}$ & 0.68 & 0.47 & 0.01 & & & & & & \\
\hline 3. Education level & 4.02 & 0.83 & 0.00 & $-0.14^{*}$ & & & & & \\
\hline 4. Organization tenure & 2.88 & 1.15 & $0.64^{* * *}$ & 0.07 & $-0.14^{*}$ & & & & \\
\hline 5. High-performance work systems & 4.11 & 0.48 & 0.02 & -0.05 & 0.05 & 0.02 & $(.91)$ & & \\
\hline 6. Psychological empowerment & 4.32 & 0.61 & 0.03 & 0.04 & 0.04 & 0.04 & $0.45^{* * *}$ & $(.96)$ & \\
\hline 7. Proactive Behavior & 4.26 & 0.64 & -0.01 & -0.01 & 0.03 & -0.00 & $0.55^{* * *}$ & $0.47^{* * *}$ & $(.87)$ \\
\hline
\end{tabular}

Notes. $N=247$ employees. Reliabilities (coefficient alpha) appear in parentheses on the diagonal;

${ }^{\text {a }}$ Male $=1$, female $=0$;

${ }^{*} p<.05 .{ }^{* *} p<.01 .{ }^{* * *} p<.001$.

\subsection{Hypotheses Testing}

To test all Hypotheses, we conducted regression analysis. The first hypothesis describes the relationship between HPWS and proactive behavior. As per our prediction in Table 3, Model 2, we found a significantly positive relationship between HPWS and proactive behavior $(\beta=0.74, t$-statistic $=10.31, p<0.001)$. Hence, hypothesis 1 receives support. In our second hypothesis, we assumed that HPWS might be related to psychological empowerment. The results reveal that HPWS is positively related to psychological empowerment $(\beta=0.56$, $t$-statistic $=7.76, p<0.001$, Model 1). Thus, hypothesis 2 is supported. In Hypothesis 3, we predicted the influence of psychological empowerment on proactive behavior. The analyses of the study suggest the significantly positive relationship between psychological empowerment and proactive behavior $(\beta=0.50, t$-statistic $=8.40, p<0.001$, Model 3). Therefore, hypothesis 3 is supported. In hypothesis 4, we proposed the mediating role of psychological empowerment in the influence of HPWS on proactive behavior. Baron and Kenny's (1986) procedures were followed to measure the mediating impact. The results suggest the partial mediating role of psychological empowerment in the impact of HPWS on proactive behavior, as the impact of HPWS on proactive behavior was decreased (from $\beta=0.74$ to 0.57 ) when psychological empowerment and HPWS were both predicted in Model 4. Furthermore, following Baron and Kenny's (1986) procedure, the Sobel test (Sobel, 1982) was conducted to measure the indirect effect's significant level. The outcomes indicated that the test statistic for HPWS $(z=4.24, p$ $<0.001$ ) predicted psychological empowerment as a significant mediator. 
Table 3. Hierarchical regression analysis

\begin{tabular}{lcccc}
\hline Variables & \multicolumn{2}{c}{ PE } & \multicolumn{2}{c}{ Proactive behavior } \\
\cline { 2 - 5 } & Model 1 & Model 2 & Model 3 & Model 4 \\
\hline Control variables & & & & $-0.01(0.06)$ \\
Age & $-0.00(0.06)$ & $-0.01(0.06)$ & $-0.01(0.06)$ & $0.04(0.07)$ \\
Gender & $0.09(0.08)$ & $0.03(0.07)$ & $-0.04(0.08)$ & $-0.01(0.04)$ \\
Education level & $0.02(0.04)$ & $-0.00(0.04)$ & $0.00(0.04)$ & $-0.01(0.04)$ \\
$\quad$ Organization tenure & $0.02(0.04)$ & $-0.00(0.04)$ & $-0.01(0.06)$ & $0.57^{* * *}(0.08)$ \\
\hline Independent Variables & & & & $0.30^{* * *}(0.06)$ \\
\hline High-performance work systems & $0.56^{* * *}(0.07)$ & $0.74^{* * *}(0.07)$ & & $23.67^{* * *}$ \\
Psychological empowerment (PE) & & & $0.50^{* * *}(0.06)$ & 0.37 \\
$F$ & $12.41^{* * *}$ & $21.32^{* * *}$ & $14.16^{* * *}$ & 0.36 \\
$R^{2}$ & 0.21 & 0.31 & 0.21 & 0.06 \\
Adjusted $R^{2}$ & 0.19 & 0.29 & & 0.36 \\
$\Delta R^{2}$ & & & & \\
\hline
\end{tabular}

Notes. Values in parentheses are standard errors; entries are unstandardized coefficients.

${ }^{\mathrm{a}}$ Male $=1$, female $=0$;

${ }^{*} p<.05 .{ }^{* *} p<.01 .{ }^{* * *} p<.001$.

\section{Discussion}

We illustrated that HPWS motivate employees to have a positive psychological empowerment and influence them to display proactive behavior. This study extends the extant SHRM literature explaining how HPWS impact employee proactive behavior. In prior research, it was not clear the linkage between the employee perceived HPWS and employee proactive behavior. Although past research reveals the impact of HPWS on extra-role behavior such as organizational citizenship behavior and creativity behavior, this study explores employee proactive behavior as an outcome of HPWS. As per our prediction and analyses, this study found significantly positive influence of employee perceived HPWS on proactive behavior. The present study has clearly articulated the research call of Grant and Ashford (2008), identifying HPWS as situational cues impact on proactive behavior.

Furthermore, this study reveals that employee perceived HPWS is positively related to psychological empowerment. This finding is analogous with the previous researches (Aryee et al., 2012; Liao et al., 2009), which identified experienced HPWS as a situational perception, motivates employee to experience high level of psychological empowerment. Moreover, several studies examined the impact of HPWS on employee psychological empowerment in the past research, such as in Ghana (Aryee et al., 2012), in USA (Butts et al., 2009), in Australia (Bonias, Bartram, Leggat, \& Stanton, 2010) and in Japan (Liao et al., 2009). This study endorses the impact of HPWS on psychological empowerment in Bangladeshi context, an emerging country in South Asia.

This study tends to contribute to the empowerment literature by incorporating proactive behavior as an outcome of employee psychological empowerment. Prior research ignores the proactive behavior as an important consequence of employee's psychological empowerment, which states the motivational impact on employee's job-related behavior. This study reveals that the feeling of empowerment influences employees to exhibit proactive behavior. Although previous studies reveal that psychological empowerment mediates the impact of HPWS on employee's in-role behavior (Aryee et al., 2012; Liao et al., 2009), work-related attitudes (Butts et al., 2009) and patient care quality (Bonias et al., 2010), a complete ignorance has been paid revealing employee proactive behavior as an important outcome. The current study posited and found the mediating role of psychological empowerment in the influence of HPWS on proactive behavior. Further study can replicate the present study by analyzing organizational citizenship behavior as the consequence of the influence of HPWS and psychological empowerment.

This study is not free from limitations. Firstly, this study is conducted in one time period; therefore the causal relationships among the variables cannot be endorsed. Future study can replicate the model with longitudinal data to identify the causal link. Secondly, to reduce the common method bias, the present study sought sample from both employees and their immediate supervisors. Furthermore, the discriminant analyses also support the limited impact of common method bias. Thirdly, as the sample has been drawn from Bangladesh, we cannot confirm the generalizability of the findings to the western countries. Finally, while studying proactive behaviors as the outcome of HPWS signifies an inclusion to the extant SHRM research, we were unable to measure the 
discriminant validity of proactive behavior with other work-related performance constructs (e.g., organizational citizenship behavior or job performance). Future research should reveal the discriminant validity among these performance constructs.

\section{Conclusion}

The results suggest that organization, incorporating HPWS, may stimulate its employees by empowering them. Managers should be cautious in designing and implementing HPWS in their organizations, because HR practices send messages to enhance psychological empowerment that further impact on proactive behavior. Managers should use all channels of communication, so that employees can perceive the exact messages of HR systems. This study reveals that psychological empowerment mediates the relationship between employee perceptions of HPWS and employee proactive behavior. Future research may unfold the effects of variables that can also mediate the influence of HPWS on proactive behaviors, such as perceived organizational support.

\section{References}

Amabile, T. M., Conti, R., Coon, H., Lazenby, J., \& Herron, M. (1996). Assessing the work environment for creativity. Academy of Management Journal, 39(5), 1154-1184. http://dx.doi.org/10.2307/256995

Appelbaum, E., Bailey, T., Berg, P., \& Kalleberg, A. L. (2000). Manufacturing Advantage: Why High-Performance Work Systems Pay off. Ithaca, NY: ILR Press.

Aryee, S., Walumbwa, F. O., Seidu, E. Y., \& Otaye, L. E. (2012). Impact of high-performance work systems on individual-and branch-level performance: Test of a multilevel model of intermediate linkages. Journal of Applied Psychology, 97(2), 287-300. http://dx.doi.org/10.1037/a0025739

Baron, R. M., \& Kenny, D. A. (1986). The moderator-mediator variable distinction in social psychological research: Conceptual, strategic, and statistical considerations. Journal of Personality and Social Psychology, 51(6), 1173-1182. http://dx.doi.org/10.1037/0022-3514.51.6.1173

Bateman, T. S., \& Crant, J. M. (1993). The proactive component of organizational behavior: A measure and correlates. Journal of Organizational Behavior, 14(2), 103-118. http://dx.doi.org/10.1002/job.4030140202

Becker, B. E., Huselid, M. A., Pickus, P. S., \& Spratt, M. F. (1997). HR as a source of shareholder value: Research and recommendations. Human Resource Management, 36(1), 39-47. http://dx.doi.org/10.1002/(SICI)1099-050X(199721)36:1<39::AID-HRM8>3.0.CO;2-X

Becker, B., \& Gerhart, B. (1996). The impact of human resource management on organizational performance: Progress and prospects. Academy of Management Journal, 39(4), 779-801. http://dx.doi.org/10.2307/256712

Blau, P. M. (1964). Exchange and Power in Social Life. New York: John Wiley \& Sons.

Bonias, D., Bartram, T., Leggat, S. G., \& Stanton, P. (2010). Does psychological empowerment mediate the relationship between high performance work systems and patient care quality in hospitals? Asia Pacific Journal of Human Resources, 48(3), 319-337. http://dx.doi.org/10.1177/1038411110381667

Bowen, D. E., \& Ostroff, C. (2004). Understanding HRM-firm performance linkages: The role of the "strength" of the HRM system. Academy of Management Review, 29(2), 203-221. http://dx.doi.org/10.5465/AMR.2004.12736076

Brislin, R. W. (1980). Translation and content analysis of oral and written material. Handbook of Cross-Cultural Psychology, 2(2), 349-444.

Butts, M. M., Vandenberg, R. J., DeJoy, D. M., Schaffer, B. S., \& Wilson, M. G. (2009). Individual Reactions to High Involvement Work Processes: Investigating the Role of Empowerment and Perceived Organizational Support. Journal of Occupational Health Psychology, 14(2), 122-136. http://dx.doi.org/10.1037/a0014114

Carvalho, V. S., \& Chambel, M. J. (2014). Work-to-Family Enrichment and Employees' Well-Being: High Performance Work System and Job Characteristics. Social Indicators Research, 119(1), 373-387. http://dx.doi.org/10.1007/s11205-013-0475-8

Castanheira, F., \& Chambel, M. J. (2010). Reducing burnout in call centers through HR practices. Human Resource Management, 49(6), 1047-1065. http://dx.doi.org/10.1002/hrm.20393

Chang, S., Jia, L., Takeuchi, R., \& Cai, Y. (2014). Do high-commitment work systems affect creativity? A multilevel combinational approach to employee creativity. Journal of Applied Psychology, 99(4), 665-680. http://dx.doi.org/10.1037/a0035679 
Chuang, C. H., \& Liao, H. (2010). Strategic human resource management in service context: Taking care of business by taking care of employees and customers. Personnel Psychology, 63(1), 153-196. http://dx.doi.org/10.1111/j.1744-6570.2009.01165.x

Crant, J. M. (2000). Proactive behavior in organizations. Journal of Management, 26(3), 435-462. http://dx.doi.org/10.1177/014920630002600304

Den Hartog, D. N., \& Belschak, F. D. (2012). When does transformational leadership enhance employee proactive behavior? The role of autonomy and role breadth self-efficacy. Journal of Applied Psychology, 97(1), 194-202. http://dx.doi.org/10.1037/a0024903

Gilson, L. L., \& Shalley, C. E. (2004). A little creativity goes a long way: An examination of teams' engagement in creative processes. Journal of Management, 30(4), 453-470. http://dx.doi.org/10.1016/j.jm.2003.07.001

Grant, A. M., \& Ashford, S. J. (2008). The dynamics of proactivity at work. In L. L. Cummings \& B. M. Staw (Eds.), Research in Organizational Behavior (Vol. 28, pp. 3-34). Greenwich, CT: JAI.

Kehoe, R. R., \& Wright, P. M. (2013). The impact of high-performance human resource practices on employees' attitudes and behaviors. Journal of Management, 39(2), 366-391. http://dx.doi.org/10.1177/0149206310365901

Kline, R. B. (1998). Principles and Practice of Structural Equation Modeling. Guilford, New York.

Lepak, D. P., \& Snell, S. A. (2002). Examining the human resource architecture: The relationships among human capital, employment, and human resource configurations. Journal of Management, 28(4), 517-543. http://dx.doi.org/10.1177/014920630202800403

Liao, H., Toya, K., Lepak, D. P., \& Hong, Y. (2009). Do they see eye to eye? Management and employee perspectives of high-performance work systems and influence processes on service quality. Journal of Applied Psychology, 94(2), 371-391. http://dx.doi.org/10.1037/a0013504

Liden, R. C., Wayne, S. J., \& Sparrowe, R. T. (2000). An examination of the mediating role of psychological empowerment on the relations between the job, interpersonal relationships, and work outcomes. Journal of Applied Psychology, 85(3), 407-416. http://dx.doi.org/10.1037/0021-9010.85.3.407

Menon, S. (2001). Employee empowerment: An integrative psychological approach. Applied Psychology, 50(1), 153-180. http://dx.doi.org/10.1111/1464-0597.00052

Morrison, E. W., \& Phelps, C. C. (1999). Taking charge at work: Extrarole efforts to initiate workplace change. Academy of management Journal, 42(4), 403-419. http://dx.doi.org/10.2307/257011

Parker, S. K., \& Collins, C. G. (2010). Taking stock: Integrating and differentiating multiple proactive behaviors. Journal of Management, 36(3), 633-662. http://dx.doi.org/10.1177/0149206308321554

Parker, S. K., Williams, H. M., \& Turner, N. (2006). Modeling the antecedents of proactive behavior at work. Journal of Applied Psychology, 91(3), 636-652. http://dx.doi.org/10.1037/0021-9010.91.3.636

Schuler, R. S., \& Jackson, S. E. (1987). Linking competitive strategies with human resource management $\begin{array}{llll}\text { practices. Academy of } & \text { Management }\end{array}$ http://dx.doi.org/10.5465/AME.1987.4275740

Segars, A. H. (1997). Assessing the unidimensionality of measurement: a paradigm and illustration within the context of information systems research. Omega, 25(1), 107-121. http://dx.doi.org/10.1016/S0305-0483(96)00051-5

Seibert, S. E., Wang, G., \& Courtright, S. H. (2011). Antecedents and consequences of psychological and team empowerment in organizations: A meta-analytic review. Journal of Applied Psychology, 96(5), 981-1003. http://dx.doi.org/10.1037/a0022676

Sobel, M. E. (1982). Asymptotic confidence intervals for indirect effects in structural equation models. In S. Leinhart (Ed.), Sociological Methodology 1982 (pp. 290-312). San Francisco: Jossey-Bass.

Spreitzer, G. M. (1995). Psychological empowerment in the workplace: Dimensions, measurement, and validation. Academy of Management Journal, 38(5), 1442-1465. http://dx.doi.org/10.2307/256865

Sun, L. Y., Aryee, S., \& Law, K. S. (2007). High-performance human resource practices, citizenship behavior, and organizational performance: A relational perspective. Academy of Management Journal, 50(3), 558-577. http://dx.doi.org/10.5465/AMJ.2007.25525821

Takeuchi, R., Lepak, D. P., Wang, H., \& Takeuchi, K. (2007). An empirical examination of the mechanisms 
mediating between high-performance work systems and the performance of Japanese organizations. Journal of Applied Psychology, 92(4), 1069-1083. http://dx.doi.org/10.1037/0021-9010.92.4.1069

Wright, P. M., \& Boswell, W. R. (2002). Desegregating HRM: A review and synthesis of micro and macro human resource management research. Journal of Management, 28(3), 247-276. http://dx.doi.org/10.1177/014920630202800302

\section{Copyrights}

Copyright for this article is retained by the author(s), with first publication rights granted to the journal.

This is an open-access article distributed under the terms and conditions of the Creative Commons Attribution license (http://creativecommons.org/licenses/by/3.0/). 